\title{
THE DERIVATION OF 1a-DEMETHYLMITOMYCIN G FROM MITOMYCIN C
}

\author{
Motomichi Kono ${ }^{\dagger}$, Masaji KasaI*, ${ }^{\dagger}$ and KuniKatsu Shirahata \\ Tokyo Research Laboratories, Kyowa Hakko Kogyo Co., Ltd., \\ 3-6-6 Asahimachi, Machida, Tokyo 194, Japan

\section{MAKOTO MORIMOTO} \\ Pharmaceutical Research Laboratories, Kyowa Hakko Kogyo Co., Ltd., \\ 1188 Shimotogari, Nagaizumi, Sunto, Shizuoka 411, Japan
}

(Received for publication May 1, 1989)

\begin{abstract}
Mitomycin G (2) was derived from porfiromycin (10b) in 3 steps via the methanesulfonate (14b) in an overall yield of $39 \%$. On the basis of the established method for the introduction of an exomethylene group in mitomycins with a 9a-methoxy group, the preparation of biologically more important la-demethylmitomycin G (5) from mitomycin $\mathbf{C}$ (1) was accomplished by the use of a protective acetyl group on the aziridine in an overall yield of $57 \%$. la-Demethylmitomycin $\mathrm{K}$ (6) was obtained from 5 in a yield of $42 \%$. In a preliminary evaluation of their antitumor activity, compound 5 showed superior activity against sarcoma 180 (sc-ip) to its 1a-methyl congener, i.e., mitomycin G (2).
\end{abstract}

Mitomycin C (1) is an antitumor antibiotic which is clinically used against a wide range of tumors. ${ }^{1)}$ Considerable research efforts have been made to clarify the mechanism of action of $\mathbf{1}$ and have revealed that the activated mitomycin could bind bifunctionally to nucleotide bases of DNA. ${ }^{2 \sim 6)}$ Recently great attention has been given to the study of mitomycin analogs. ${ }^{7 \sim 12)}$ As part of our effort to obtain more potent mitomycin derivatives, we have screened the minor components from the fermentation broth, and have identified mitomycins $\mathrm{D}, \mathrm{E}, \mathrm{F}, \mathrm{G},{ }^{13)} \mathrm{H},{ }^{14)} \mathrm{I}, \mathrm{J}, \mathrm{K}, \mathrm{L}, \mathrm{M},{ }^{13)}$ albomitomycin $\mathrm{A}$, and isomitomycin A. ${ }^{15)}$ Among them, mitomycins G (2), H (3), and K (4) have an exo-methylene group at the C-9 position, and are therefore potentially biologically significant molecules in a sense that the C-10 position could be an electrophilic center as in $1 .^{2 \sim 6)}$ We herein, report the first synthesis of 2 from porfiromycin (10b) and mitomycin E (10a). In other words, these are the first examples of introduction of an exo-methylene functionality in mitomycins with a 9a-methoxy group. In addition the introduction of the exo-methylene from 1 was achieved to afford la-demethylmitomycins $G(5)$ and $K(6)$, which attracted our interest from the viewpoint of biological activity due to their structural similarity to the unsubstituted aziridine of 1 .

In previous studies ${ }^{16,17)}$ on the introduction of double bond at the C-9 and C-10 positions in mitomycins with 9a-hydroxy group, the conversions of mitomycin $\mathbf{B}(\mathbf{8})$ to $\mathbf{3}$ and mitomycin $\mathrm{D}$ (9) to $9 \mathrm{a}-O$-demethylmitomycin $\mathrm{G}(7)$ have been achieved. However the fermentation yields of naturally occurring 8 and 9 were quite low ${ }^{\dagger \dagger}$ compared to that of $\mathbf{1}$. Accordingly, in order to extend the availability of 2 , we employed 1 as a starting material. Firstly, we attempted the introduction of an exo-methylene bond in $10 \mathrm{~b}$ (with $9 \beta$ configuration), which was readily derived from $1{ }^{19)}$ However application of the same condition

† Present address: Pharmaceutical Research Laboratories, Kyowa Hakko Kogyo Co., Ltd., 1188 Shimotogari, Nagaizumi, Sunto, Shizuoka 411, Japan.

t† Recently ARAI reported ${ }^{18)}$ the efforts to increase the fermentation yield of 8 . 
Fig. 1. The structure of mitomycins.<smiles>COC12C3NC3CN1C1=C(C(=O)C(N)=C(C)C1=O)[C@@H]2COC(N)=O</smiles>

1<smiles>[X]C1=C(C)C(=O)C2=C(C1=O)C(=O)[C@]1(O)C3[Y1]C3CN21</smiles>

$2 \mathrm{X}=\mathrm{NH}_{2} \quad \mathrm{Y}=\mathrm{Z}=\mathrm{CH}_{3}$

$3 \mathrm{X}=\mathrm{OCH}_{3}$

$4 \mathrm{X}=\mathrm{OCH}_{3}$

$5 \mathrm{X}=\mathrm{NH}_{2}$

$6 \mathrm{X}=\mathrm{OCH}_{3}$

$7 \mathrm{X}=\mathrm{NH}$
$\mathrm{Y}=\mathrm{Z}=\mathrm{CH}_{3}$

$$
\mathrm{Y}=\mathrm{CH}_{3}
$$

$\mathrm{Y}=\mathrm{CH}_{3}$

$\mathrm{Y}=\mathrm{H}$<smiles>[X]C1=C(C)C(=O)C2=C(C1=O)C(COC(N)=O)C1(O)C3[C@H](C2)CN31</smiles>

$8 \mathrm{X}=\mathrm{OCH}_{3}$

$9 \mathrm{X}=\mathrm{NH}_{2}$
$\mathrm{Z}=\mathrm{CH}_{3}$

$\mathrm{Z}=\mathrm{H}$

$\mathrm{Z}=\mathrm{H}$

$\mathrm{Z}=\mathrm{CH}_{3}$

Equation 1:

$10 \mathrm{a}(9: \alpha)$

10b $(9: \beta)$

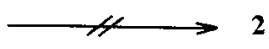

Equation 2:

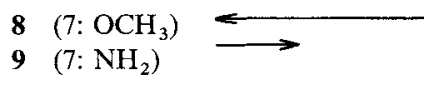<smiles>[X]C1=C(C)C(=O)C2=C(C1=O)C(COC(N)=O)C(=O)C1NC1CNC2=O</smiles>

(DBU/THF, described in our previous article ${ }^{17)}$ ) to $10 \mathrm{~b}$ failed to afford the desired compound and resulted in the recovery of $\mathbf{1 0 b}$. Next we tried to apply the same condition to $10 \mathrm{a},{ }^{\dagger \dagger}$ since the $\beta$ elimination in 10a might be facilitated by the steric hindrance between cis C-9 and C-9a substituents. Nevertheless such a trial also ended in failure resulting in the recovery of 10a (equation 1). These results suggested that in compounds having 9a-hydroxy group like 8 and 9, a strong base imparted a carbonyl character to the $9 \mathrm{a}$ position due to the resonance structures 11 and 12 (equation 2). The resultant acidic C-9 proton could be abstracted by a base leading to a smooth $\beta$ elimination to give the exo-methylene compound. In contrast, in 9a-methoxy compounds there would be no contribution of resonance structure mentioned above and thus the acidity of the C-9 proton would be negligible.

To circumvent the difficulty of introducing an exo-methylene bond in $\mathbf{1 0 b}$, the carbamate was converted to the methanesulfonate $(\mathbf{1 4 b})$ in a conventional way to increase the leaving ability. The reaction of $10 \mathrm{~b}$ with sodium alkoxide afforded decarbamoylporfiromycin $(\mathbf{1 3 b}),{ }^{20)}$ and subsequent methanesulfonylation with methanesulfonyl chloride gave the desired sulfonate $\mathbf{1 4 b}$. This change of leaving group resulted in a successful $\beta$ elimination in $14 \mathbf{b}$ by DBU to afford the desired product 2 in good yield. Thus we obtained 2 from $10 \mathrm{~b}$ by 3 steps in an overall yield of $39 \%$. Next we examined 10a with the same process, and also succeeded in the introduction of exo-methylene bond at the C-9 position.

tt The fermentation yield of 10a was also quite low. Consequently, mitomycin E (10a) was derived from 8 by 2 steps: (1) Methylation at the $9 \mathrm{a}-\mathrm{OH}$ position ${ }^{17)}$ and (2) amination at the $\mathrm{C}-7$ position ${ }^{19)}$ in an overall yield of $44 \%$. 
Scheme 1.<smiles>COC12C(COC(N)=O)C3=C(C(=O)C(C)=C(N)C3=O)N1CC1C(C)C12</smiles>

10a $(9: \alpha)$ 10b $(9: \beta)$<smiles>[R]OCC1C2=C(C(=O)C(C)=C(N)C2=O)N2CC3C([C@@H]3C)C12OC</smiles>

13a, 13b $\quad \mathrm{R}=\mathrm{H}$

14a, 14b $\mathrm{R}=\mathrm{SO}_{2} \mathrm{CH}_{3}$

a: 2-PrONa, 2-PrOH, room temperature, $10 \mathrm{a} \rightarrow 13 \mathrm{a} ; 58 \%, 10 \mathrm{~b} \rightarrow 13 \mathrm{~b} ; 68 \%$. b: $\mathrm{CH}_{3} \mathrm{SO}_{2} \mathrm{Cl}$, pyridine, room temperature, 13a $\rightarrow 14 a ; 98 \%, 13 b \rightarrow 14 b ; 98 \%$. c: DBU, THF, reflux, $14 a \rightarrow 2 ; 65 \%, 14 b \rightarrow 2 ; 59 \%$.

Scheme 2.

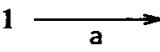

17

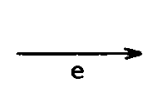<smiles>COC12C(CO)C3=C(C(=O)C(C)=C(N)C3=O)N1CC1NC12</smiles>

15<smiles>C=C1C2=C(C(=O)C(C)=C(N)C2=O)N2CC3C([C@H]3N2C)C1(C)C</smiles>

19

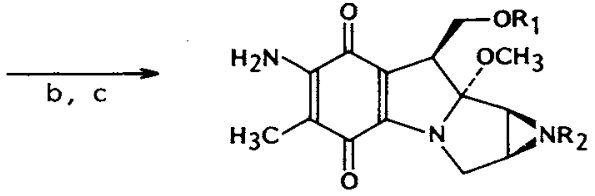

$16 \mathrm{R}_{1}=\mathrm{H} \quad \mathrm{R}_{2}=\mathrm{Ac}$

$\mathrm{d}\left[\begin{array}{lll}17 & \mathrm{R}_{1}=\mathrm{SO}_{2} \mathrm{CH}_{3} & \mathrm{R}_{2}=\mathrm{Ac} \\ 18 & \mathrm{R}_{1}=\mathrm{SO}_{2} \mathrm{CH}_{3} & \mathrm{R}_{2}=\mathrm{H}\end{array}\right.$

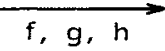

$\begin{array}{rl}5 & \mathrm{X}=\mathrm{NH}_{2} \\ \mathbf{2 0} & \mathrm{X}=\mathrm{OH} \\ \mathbf{6} & \mathrm{X}=\mathrm{OCH}_{3}\end{array}$

a: 2-PrONa, 2-PrOH, room temperature; $78 \%$. b: $\mathrm{Ac}_{2} \mathrm{O}$, pyridine, $0^{\circ} \mathrm{C} ; 97 \%$. $\mathrm{c}: \mathrm{CH}_{3} \mathrm{SO}_{2} \mathrm{Cl}$, pyridine, $-15^{\circ} \mathrm{C} ; 97 \%$. d: $\mathrm{NaHCO}_{3},\left(\mathrm{CH}_{3}\right)_{2} \mathrm{CO}-\mathrm{H}_{2} \mathrm{O}$, room temperature; $41 \%$. e: DBU, dimethoxyethane, reflux; $82 \%$. f: pyrrolidine, $\mathrm{MeOH}$, room temperature; $94 \%$. g: $\mathrm{NaOH}, \mathrm{MeOH}-\mathrm{H}_{2} \mathrm{O}$, room temperature; $66 \%$. h: $\mathrm{CH}_{2} \mathrm{~N}_{2} ; 63 \%$.

In the next stage of efforts, we extended this approach to prepare biologically more important 1a-demethylmitomycin derivatives, since generally they showed higher antitumor activities than 1a-methyl relatives. ${ }^{21)}$ The protection of the aziridine was needed to derive a la-demethylmitomycin with exo-methylene from 1. The acrolein adduct and its derivatives were used in the KISHI's total synthesis of $1 .^{22,23)}$ Through the course of our reactions, we found the 1a-acetate was an excellent protecting group of the aziridine. ${ }^{24)}$ The mild deprotection was proceeded from 1a-acetate on treatment with secondary amines (C. URAKAWA; personal communication) or sodium hydrogen carbonate. ${ }^{24)}$

Mitomycin C (1) was treated with sodium 2-propoxide to give the alcohol (15). ${ }^{20}$ The protection of the aziridine was proceeded by using acetic anhydride, and subsequent methanesulfonylation afforded the methanesulfonyl acetate (17). These two steps could be conducted in one pot reaction in a yield of $90 \%$. Exo-methylene was induced from 17 on treatment with $\mathrm{DBU}$ in dimethoxyethane at $82^{\circ} \mathrm{C}$ in a better yield than in THF at $66^{\circ} \mathrm{C}$. Finally the clean and mild deprotection of 19 was accomplished on treatment with 
Table 1. Antitumor activity of mitomycin derivatives.

\begin{tabular}{|c|c|c|c|c|}
\hline \multirow{2}{*}{ No. } & \multicolumn{4}{|c|}{ Sarcoma 180 (sc-ip) } \\
\hline & $\mathrm{LD}_{50}$ ip $(\mathrm{mg} / \mathrm{kg})$ & $\mathrm{ED}_{50}$ ip $(\mathrm{mg} / \mathrm{kg})$ & $\mathrm{CI}\left(\mathrm{LD}_{50} / \mathrm{ED}_{50}\right)$ & $\mathrm{WBC}_{4000}(\mathrm{mg} / \mathrm{kg})$ \\
\hline 2 & 131 & 102 & 1.3 & $>100$ \\
\hline $\mathbf{3}^{\mathrm{a}}$ & 11.7 & 6.8 & 0.72 & $>12.5$ \\
\hline $4^{a}$ & 22.4 & 35 & 0.66 & 30 \\
\hline $7^{b}$ & 210 & 82 & 2.6 & $>200$ \\
\hline 5 & 75 & 26 & 2.9 & $>50$ \\
\hline 6 & 13 & 7.5 & 1.8 & 14 \\
\hline 18 & $>200$ & $>200$ & - & $>200$ \\
\hline 1 & 8.4 & 3.7 & 2.3 & 2.7 \\
\hline
\end{tabular}

a The preparation of the compound was described in the ref 17 .

b The values were quoted from the ref 16 .

The $\mathrm{LD}_{50}$ values were determined in $d d \mathrm{Y}$ mice ( 5 mice/group) after 14 days of observation and were calculated by Behrens-Karber analysis. Sarcoma 180 cells $\left(5 \times 10^{6} /\right.$ mouse $)$ were implanted sc into $d d \mathrm{Y}$ mice and the drug was administered ip respectively on day $1 . \mathrm{ED}_{50}$ values were doses which gave $50 \%$ inhibition of tumor growth on day $7 . \mathrm{WBC}_{4000}$ values were doses to give a $\mathrm{WBC}$ number of $4000 / \mathrm{mm}^{3}$ on day 4 .

secondary amine, i.e., pyrrolidine or diisopropylamine in excellent yields. Thus $\mathbf{5}$ was obtained from $\mathbf{1}$ in an overall yield of $57 \%$ via 17. In addition, the conversion of the amino group at the C-7 position in 5 to the methoxy group was carried out by the known method, ${ }^{25,26)}$ hydrolysis of 5 afforded 20 and subsequent methylation gave the expected 6 in a yield of $42 \%$ from 5 .

\section{Antitumor Activity}

The potentially informative methanesulfonate analog (18), which had a high electrophilic center at the C-10 position, was obtained from 17 on treatment with sodium hydrogen carbonate. The activity of 18 was of interest in comparison with that of 1 . Antitumor effects against sarcoma 180 (sc-ip) of 2, 3, 4, $5,6,7$, and 18 were evaluated according to the method described in the literature. ${ }^{27)}$ Mitomycin C (1) was used as a control compound. 1a-Demethylmitomycin $G(5)$ showed wide range of effective dosage against sarcoma 180 (sc-ip) and appeared to have reduced myelosuppression in comparison to 1 . As expected the CI value of 5 was superior to that of 2 . A similar relationship between 6 and 4 was also observed. Although the higher reactivity of the C-10 substitution of 18 than that of 1,18 showed no antitumor activity. This implied premature quenching of 18 by nucleophiles in the living system before it reached the DNA target. These results will aid in the design of future mitomycin analogs and the interpretation of the structure-activity relationship among naturally occurring mitomycins and their related compounds.

\section{Experimental}

MP's were recorded on a Yanagimoto melting point apparatus and are uncorrected. ${ }^{1} \mathrm{H}$ and ${ }^{13} \mathrm{C}$ NMR spectra were recorded on a Jeol FX-100 and a JNM-PS-PFT-100 spectrometers. MS spectra were recorded on a JMS-O1SG-2 spectrometer. IR spectra were recorded on a Shimadzu IR-27-G spectrometer. Electronic spectra were recorded on a Shimadzu Spectrophotometer MPS-50L.

10-O-Decarbamoyl-10-O-methanesulfonylporfiromycin (14b)

Compound $\mathbf{1 3 b}^{\mathbf{2 0}}(100 \mathrm{mg})$ was dissolved in anhydrous pyridine $(2 \mathrm{ml})$, to which was added methanesulfonyl chloride $(50 \mu \mathrm{l})$ and the reaction mixture was stirred at room temperature for 20 minutes. Then saturated aqueous solution $(10 \mathrm{ml})$ of sodium hydrogen carbonate was added to the reaction mixture 
to quench the reaction. The mixture was extracted with ethyl acetate and dried over anhydrous sodium sulfate and concentrated in vacuo. The residue was purified by column chromatography on silica gel with chloroform - methanol ( $95: 5)$. The purple fractions were collected and concentrated in vacuo to give $123 \mathrm{mg}$ of purple solids 14b (yield; $98 \%$ ). 14b: EI-MS $m / z 383\left(\mathrm{M}^{+}, \mathrm{C}_{16} \mathrm{H}_{21} \mathrm{~N}_{3} \mathrm{O}_{6} \mathrm{~S}\right.$ ); ${ }^{1} \mathrm{H}$ NMR (pyridine- $d_{5}$ ) $\delta$ $2.03(3 \mathrm{H}, \mathrm{s}), 2.23(1 \mathrm{H}, \mathrm{dd}, J=4.6$ and $2.0 \mathrm{~Hz}), 2.32(3 \mathrm{H}, \mathrm{s}), 2.64(1 \mathrm{H}, \mathrm{d}, J=4.6 \mathrm{~Hz}), 3.19(3 \mathrm{H}, \mathrm{s}), 3.30$ $(3 \mathrm{H}, \mathrm{s}), 3.52(1 \mathrm{H}$, dd, $J=12.9$ and $2.0 \mathrm{~Hz}), 3.96(1 \mathrm{H}, \mathrm{dd}, J=11.0$ and $4.2 \mathrm{~Hz}), 4.47(1 \mathrm{H}, \mathrm{d}, J=12.9 \mathrm{~Hz})$, $4.84(1 \mathrm{H}, \mathrm{dd}, J=11.0$ and $9.5 \mathrm{~Hz}), 5.31(1 \mathrm{H}, \mathrm{dd}, J=9.5$ and $4.2 \mathrm{~Hz}), 7.64(2 \mathrm{H}, \mathrm{br})$.

\section{0-O-Decarbamoyl-10-O-methanesulfonylmitomycin E (14a)}

Compound 14a was obtained from $13 \mathrm{a}^{20}$ by the same procedure as the preparation of $14 \mathrm{~b}$ in a yield of $98 \%$. 14b: EI-MS $m / z 383\left(\mathrm{M}^{+}, \mathrm{C}_{16} \mathrm{H}_{21} \mathrm{~N}_{3} \mathrm{O}_{6} \mathrm{~S}\right) ;{ }^{1} \mathrm{H}$ NMR $\left(\mathrm{CDCl}_{3}\right) \delta 1.73(3 \mathrm{H}, \mathrm{s}), 2.34(3 \mathrm{H}, \mathrm{s}), 2.45$ $(1 \mathrm{H}, \mathrm{d}, J=4.6 \mathrm{~Hz}), 2.64(1 \mathrm{H}, \mathrm{dd}, J=4.6$ and $2.0 \mathrm{~Hz}), 3.10(3 \mathrm{H}, \mathrm{s}), 3.38(3 \mathrm{H}, \mathrm{s}), 3.64(1 \mathrm{H}, \mathrm{dd}, J=12.9$ and $2.0 \mathrm{~Hz}), 3.84(1 \mathrm{H}, \mathrm{dd}, J=10.5 \mathrm{and} 3.7 \mathrm{~Hz}), 3.93(1 \mathrm{H}, \mathrm{d}, J=12.9 \mathrm{~Hz}), 4.50(1 \mathrm{H}, \mathrm{dd}, J=10.5$ and $9.8 \mathrm{~Hz})$, $4.92(1 \mathrm{H}, \mathrm{dd}, J=9.8$ and $3.7 \mathrm{~Hz})$.

\section{Mitomycin G (2 from $14 b$ or $14 a)$}

The compound $14 \mathrm{~b}(17 \mathrm{mg})$ was dissolved in anhydrous tetrahydrofuran $(1 \mathrm{ml})$, to which was added 1,5-diazabicyclo[5.4.0]undec-5-ene (54 mg) and the reaction mixture was refluxed under nitrogen atmosphere for 5 hours. The solvent was removed under reduced pressure and the residue was purified by column chromatography on silica gel with chloroform-acetone $(4: 1)$. The green fractions were collected and concentrated in vacuo to give $7.5 \mathrm{mg}$ of dark green needles of 2 (yield; $59 \%$ ). 2: MP $238 \sim 241^{\circ} \mathrm{C}$ (dec). All the spectroscopic data were identical with those of reported ones. ${ }^{16)}$ Compound 2 was obtained from 14a according to the same procedure as mentioned above in a yield of $65 \%$.

\section{0-O-Decarbamoylmitomycin C (15)}

Compound 15 was prepared according to the procedure described in the literature ${ }^{20)}$ in a yield of $78 \%$.

\section{1a-Acetyl-10-O-decarbamoylmitomycin C (16)}

Compound $15(138 \mathrm{mg})$ was dissolved in anhydrous pyridine $(1 \mathrm{ml})$, to which was added acetic anhydride $(60 \mu 1)$ at $0^{\circ} \mathrm{C}$ and the reaction mixture was stirred under nitrogen atmosphere for 1 hour. Then the reaction mixture was poured into a saturated aqueous sodium hydrogen carbonate solution and the mixture was extracted with ethyl acetate. The extract was washed with water and dried over anhydrous sodium sulfate and concentrated in vacuo. The residue was purified by column chromatography on silica gel using chloroform - methanol $(95: 5)$. The purple fractions. were collected and concentrated in vacuo to give $153 \mathrm{mg}$ of purplish black solids of 16 (yield; 97\%). 16: EI-MS $m / z 333\left(\mathrm{M}^{+}, \mathrm{C}_{16} \mathrm{H}_{19} \mathrm{~N}_{3} \mathrm{O}_{5}\right) ;{ }^{1} \mathrm{H}$ NMR (pyridine- $d_{5}$ ) $\delta 2.05(3 \mathrm{H}, \mathrm{s}), 2.23(3 \mathrm{H}, \mathrm{s}), 3.23(3 \mathrm{H}, \mathrm{s}), 3.57(1 \mathrm{H}, \mathrm{dd}, J=4.6$ and $2.0 \mathrm{~Hz}), 3.66(1 \mathrm{H}, \mathrm{dd}, J=13.2$ and $2.0 \mathrm{~Hz}), 3.94(1 \mathrm{H}, \mathrm{dd}, J=9.5$ and $5.7 \mathrm{~Hz}), 3.98(1 \mathrm{H}, \mathrm{d}, J=4.6 \mathrm{~Hz}), 4.33(1 \mathrm{H}, \mathrm{dd}, J=10.6 \mathrm{and} 9.5 \mathrm{~Hz}), 4.76$ $(1 \mathrm{H}, \mathrm{d}, J=13.2 \mathrm{~Hz}), 4.84(1 \mathrm{H}, \mathrm{dd}, J=10.6$ and $5.7 \mathrm{~Hz}), 7.57(2 \mathrm{H}, \mathrm{br}) ; \mathrm{IR}(\mathrm{KBr}) \mathrm{cm}^{-1} 3435,3335,1694$, 1605,1555 .

\section{1a-Acetyl-10-O-decarbamoyl-10- $O$-methanesulfonylmitomycin $\mathrm{C}$ (17)}

Compound $16(62 \mathrm{mg})$ was dissolved in anhydrous pyridine $(0.33 \mathrm{ml})$, to which was added methanesulfonyl chloride $(15 \mu 1)$ under nitrogen atmosphere at $-15^{\circ} \mathrm{C}$ and the reaction mixture was stirred for 2 hours. Then the reaction mixture was poured into a saturated aqueous solution of sodium hydrogen carbonate and the mixture was extracted with ethyl acetate. The extract was washed with water and dried over anhydrous sodium sulfate and concentrated in vacuo. The residue was purified by column chromatography on silica gel using chloroform - methanol (96:4). The purple fractions were collected and concentrated in vacuo to give $74 \mathrm{mg}$ of purplish black solids of 17 (yield; 97\%). 17: ${ }^{1} \mathrm{H}$ NMR (pyridine- $d_{5}$ ) $\delta 2.04(3 \mathrm{H}, \mathrm{s}), 2.11(3 \mathrm{H}, \mathrm{s}), 3.20(3 \mathrm{H}, \mathrm{s}), 3.46(3 \mathrm{H}, \mathrm{s}), 3.60(1 \mathrm{H}, \mathrm{dd}, J=4.5$ and $1.6 \mathrm{~Hz}), 3.61(1 \mathrm{H}$, dd, $J=13.7$ and $1.6 \mathrm{~Hz}), 3.79(1 \mathrm{H}, \mathrm{d}, J=4.5 \mathrm{~Hz}), 4.09(1 \mathrm{H}, \mathrm{dd}, J=10.7$ and $4.2 \mathrm{~Hz}), 4.84(1 \mathrm{H}, \mathrm{d}, J=13.7 \mathrm{~Hz})$, $4.84(1 \mathrm{H}, \mathrm{dd}, J=10.7$ and $9.8 \mathrm{~Hz}), 5.58(1 \mathrm{H}, \mathrm{dd}, J=9.8$ and $4.2 \mathrm{~Hz}), 7.71(2 \mathrm{H}, \mathrm{br}) ; \mathrm{IR}(\mathrm{KBr}) \mathrm{cm}^{-1} 3445$, $3235,1697,1605,1563,1350,1173$. 
1a-Demethyl-1a-acetylmitomycin G (19)

Compound $17(38 \mathrm{mg})$ was dissolved in anhydrous ethylene glycol dimethyl ether $(8 \mathrm{ml})$, to which was added 1,5-diazabicyclo[5.4.0]undec-5-ene $(150 \mathrm{mg})$ and the reaction mixture was refluxed under nitrogen atmosphere for 2 hours. A saturated aqueous sodium hydrogen carbonate solution was added to the reaction mixture and the mixture was extracted with ethyl acetate. The extract was washed with water and dried over anhydrous sodium sulfate and concentrated in vacuo. The residue was purified by column chromatography on silica gel using chloroform-acetone $(6: 4)$. The bluish green fractions were collected and concentrated in vacuo to give $24 \mathrm{mg}$ of bluish green solids of 19 (yield; 82\%). 19: ${ }^{1} \mathrm{H}$ NMR (pyridine- $d_{5}$ ) $\delta 2.03(3 \mathrm{H}, \mathrm{s}), 2.05(3 \mathrm{H}, \mathrm{s}), 3.17(3 \mathrm{H}, \mathrm{s}), 3.57(1 \mathrm{H}, \mathrm{dd}, J=4.5$ and $1.6 \mathrm{~Hz}), 3.64(1 \mathrm{H}, \mathrm{dd}, J=13.2$ and $1.6 \mathrm{~Hz}), 3.78(1 \mathrm{H}, \mathrm{d}, J=4.5 \mathrm{~Hz}), 4.84(1 \mathrm{H}, \mathrm{d}, J=13.2 \mathrm{~Hz}), 5.61(1 \mathrm{H}, \mathrm{d}, J=0.7 \mathrm{~Hz}), 6.55(1 \mathrm{H}, \mathrm{d}, J=0.7 \mathrm{~Hz})$, $7.76(2 \mathrm{H}, \mathrm{br}) ; \mathrm{IR}(\mathrm{KBr}) \mathrm{cm}^{-1} 3435,3330,1695,1656,1694,1537$.

\section{1a-Demethylmitomycin G (5)}

Compound $19(143 \mathrm{mg})$ was dissolved in methanol $(4.5 \mathrm{ml})$, to which was added pyrrolidine $(0.3 \mathrm{ml})$ and the reaction mixture was stirred at room temperature for 30 minutes. The solvent was removed in vacuo and the residue was purified by column chromatography on silica gel with chloroform-acetone $(1: 1)$. The bluish green fractions were collected and concentrated in vacuo to give $116 \mathrm{mg}$ of dark green prisms of 5 (yield; $94 \%$ ). 5: MP $149 \sim 151^{\circ} \mathrm{C}$; EI-MS (HR) calcd for $\mathrm{C}_{14} \mathrm{H}_{15} \mathrm{~N}_{3} \mathrm{O}_{3}: m / z 273.1113$, found: $m / z$ 273.1099; UV $\lambda_{\max }^{\mathrm{MeOH}} \mathrm{nm}(\log \varepsilon) 222$ (4.15), $290(3.96), 377(4.17) ;{ }^{1} \mathrm{H}$ NMR (pyridine- $\left.d_{5}\right) \delta 2.00(3 \mathrm{H}$, s), $2.77(1 \mathrm{H}, \mathrm{dd}, J=4.4$ and $1.7 \mathrm{~Hz}), 3.04(1 \mathrm{H}, \mathrm{d}, J=4.4 \mathrm{~Hz}), 3.17(3 \mathrm{H}, \mathrm{s}), 3.59(1 \mathrm{H}$, dd, $J=12.7$ and $1.7 \mathrm{~Hz}), 4.67(1 \mathrm{H}, \mathrm{d}, J=12.7 \mathrm{~Hz}), 5.50(1 \mathrm{H}, \mathrm{d}, J=1.1 \mathrm{~Hz}), 6.50(1 \mathrm{H}, \mathrm{d}, J=1.1 \mathrm{~Hz}), 7.57(2 \mathrm{H}, \mathrm{br}) ;{ }^{13} \mathrm{C}$ NMR (pyridine- $d_{5}$ ) $\delta 8.9(\mathrm{q}), 33.9(\mathrm{~d}), 38.8(\mathrm{~d}), 49.8(\mathrm{t}), 50.2(\mathrm{q}), 105.7$ (s, two carbons), 108.7 (dd), 112.3 (s), $140.0(\mathrm{~s}), 149.5(\mathrm{~s}), 158.3(\mathrm{~s}), 176.2(\mathrm{~s}), 178.1(\mathrm{~s})$; IR (KBr) $\mathrm{cm}^{-1} 3420,3320,3285,1651,1592,1532$.

\section{1a-Demethyl-7-O-demethylmitomycin $\mathrm{K}$ (20)}

Compound $5(18 \mathrm{mg})$ was dissolved in $0.1 \mathrm{~N}$ aqueous sodium hydroxide solution $(3.75 \mathrm{ml})$ and the reaction mixture was stirred at room temperature for 45 minutes. The reaction mixture was adjusted to $\mathrm{pH} 4.0$ with diluted hydrochloric acid and extracted with ethyl acetate. The extract was washed with water and dried over anhydrous sodium sulfate and concentrated in vacuo. The residue was purified by column chromatography on silica gel with chloroform - methanol $(9: 1)$. The bluish purple fractions were collected and concentrated in vacuo to give $12 \mathrm{mg}$ of purplish black solids of $\mathbf{2 0}$ (yield; 66\%). 20: EI-MS $m / z 274\left(\mathrm{M}^{+}, \mathrm{C}_{14} \mathrm{H}_{14} \mathrm{~N}_{2} \mathrm{O}_{4}\right) ;{ }^{1} \mathrm{H}$ NMR (pyridine- $\left.d_{5}\right) \delta 2.05(3 \mathrm{H}, \mathrm{s}), 2.80(1 \mathrm{H}, \mathrm{dd}, J=4.5$ and $1.7 \mathrm{~Hz})$ $3.08(1 \mathrm{H}, \mathrm{d}, J=4.5 \mathrm{~Hz}), 3.19(3 \mathrm{H}, \mathrm{s}), 3.58(1 \mathrm{H}, \mathrm{dd}, J=12.6$ and $1.7 \mathrm{~Hz}), 4.50(1 \mathrm{H}, \mathrm{d}, J=12.6 \mathrm{~Hz}), 5.55$ $(1 \mathrm{H}, \mathrm{d}, J=0.9 \mathrm{~Hz}), 6.52(1 \mathrm{H}, \mathrm{d}, J=0.9 \mathrm{~Hz}) ; \mathrm{IR}(\mathrm{KBr}) \mathrm{cm}^{-1} 3285,1644,1630,1548$.

\section{la-Demethylmitomycin K (6)}

Compound $20(12 \mathrm{mg})$ was dissolved in ethyl acetate $(3 \mathrm{ml})$. An excess amount of ethyl ether solution of diazomethane was added dropwise to the solution while ice cooling and the mixture was allowed to stand for 10 minutes. The mixture was then concentrated in vacuo and the residue was purified by column chromatography on silica gel using chloroform-acetone (6:4). The bluish purple fractions were collected and concentrated in vacuo to give $8 \mathrm{mg}$ of blackish purple prisms of 6 (yield; $63 \%$ ). 6: MP $65 \sim 67.5^{\circ} \mathrm{C}$; EI-MS (HR) calcd for $\mathrm{C}_{15} \mathrm{H}_{16} \mathrm{~N}_{2} \mathrm{O}_{4}: m / z 288.1110$, found: $m / z 288.1085$; UV $\lambda_{\max }^{\mathrm{MeOH}} \mathrm{nm}(\log \varepsilon) 223(4.11)$, 288 (4.05), $322(\mathrm{sh}, 3.98) ;{ }^{1} \mathrm{H}$ NMR (pyridine- $\left.d_{5}\right) \delta 1.83(3 \mathrm{H}, \mathrm{s}), 2.80(1 \mathrm{H}, \mathrm{dd}, J=4.3$ and $1.5 \mathrm{~Hz}), 3.07$ $(1 \mathrm{H}, \mathrm{d}, J=4.3 \mathrm{~Hz}), 3.16(3 \mathrm{H}, \mathrm{s}), 3.53(1 \mathrm{H}, \mathrm{dd}, J=12.6$ and $1.5 \mathrm{~Hz}), 4.01(3 \mathrm{H}, \mathrm{s}), 4.33(1 \mathrm{H}, \mathrm{d}, J=12.5 \mathrm{~Hz})$, $5.59(1 \mathrm{H}, \mathrm{d}, J=1.0 \mathrm{~Hz}), 6.57(1 \mathrm{H}, \mathrm{d}, J=1.0 \mathrm{~Hz}) ; \mathrm{IR}(\mathrm{KBr}) \mathrm{cm}^{-1} 3285,1644,1630,1548$.

\section{0-O-Decarbamoyl-10-O-methanesulfonylmitomycin C (18)}

Compound $17(14.8 \mathrm{mg})$ was dissolved in acetone $(1 \mathrm{ml})$, to which was added aqueous solution of $10 \%$ sodium hydrogen carbonate $(1 \mathrm{ml})$. The reaction mixture was stirred at room temperature for 50 hours. The reaction mixture was extracted with ethyl acetate. The extract was washed with water and brine and dried over anhydrous sodium sulfate and concentrated in vacuo. The residue was purified by column chromatography on silica gel using ethyl acetate - methanol $(98: 2)$. The purple fractions (Rf 0.56 ) were collected and concentrated in vacuo to give $5.0 \mathrm{mg}$ of purple solids of $\mathbf{1 8}$ (yield; $41 \%$ ). From the 
second purple fractions ( $\mathrm{Rf} 0.31$ ) $1.2 \mathrm{mg}$ of 17 was recovered. 18: ${ }^{1} \mathrm{H}$ NMR (pyridine- $\left.d_{5}\right) \delta 2.04(3 \mathrm{H}, \mathrm{s}$ ), $2.82(1 \mathrm{H}, \mathrm{dd}, J=4.4$ and $2.0 \mathrm{~Hz}), 3.22(3 \mathrm{H}, \mathrm{s}), 3.23(1 \mathrm{H}, \mathrm{d}, J=4.4 \mathrm{~Hz}), 3.29(3 \mathrm{H}, \mathrm{s}), 3.63(1 \mathrm{H}, \mathrm{dd}, J=12.9$ and $2.0 \mathrm{~Hz}), 4.02(1 \mathrm{H}$, dd, $J=10.5$ and $4.8 \mathrm{~Hz}), 4.52(1 \mathrm{H}, \mathrm{d}, J=12.9 \mathrm{~Hz}), 5.18(1 \mathrm{H}$, dd, $J=10.5 \mathrm{and} 9.4 \mathrm{~Hz})$, $5.32(1 \mathrm{H}, \mathrm{dd}, J=9.4$ and $4.8 \mathrm{~Hz}), 7.66(2 \mathrm{H}, \mathrm{br})$; IR $(\mathrm{KBr}) \mathrm{cm}^{-1} 3440,3315,1604,1555,1352,1174$.

\section{References}

1) Carter, S. K. \& S. T. Crook (Ed.): Mitomycin C: Current Status and New Developments. Academic Press, 1979

2) Schwartz, H. S.; J. E. Sodergren \& F. S. Philips: Mitomycin C: Chemical and biological studies on alkylation. Science 142: $1181 \sim 1183,1963$

3) IYER, V. N. \& W. SZYBalSKi: Mitomycins and porfiromycin: Chemical mechanism of activation and cross-linking of DNA. Science 145: 55 58, 1964

4) Lown, J. W.; A. Begleiter, D. Johnson \& A. R. Morgan: Studies related to antitumor antibiotics. Part 5. Reactions of mitomycin C with DNA examined by ethidium fluorescence assay. Can. J. Biochem. 54: 110 119, 1976

5) Tomasz, M.; R. Lipman, R. Chowdary, J. Pawlak, G. C. Verdine \& K. Nakanishi: Isolation and structure of a covalent cross-link adduct between mitomycin $C$ and DNA. Science 235: 1204 1208, 1987

6) Tomasz, M.; R. LipMAn, B. F. MCGuinNess \& K. NAKANishi: Isolation and characterization of a major adduct between mitomycin C and DNA. J. Am. Chem. Soc. 110: 5892 5896, 1988

7) Iyengar, B. S.; R. T. DORR, W. A. REMERS \& C. D. Kowal: Nucleotide derivatives of 2,7-diaminomitosene. J. Med. Chem. 31: 1579 1585, 1988

8) SAmi, S. M.; B. S. IYengar, W. A. Remers \& W. T. Bradner: Preparation and antitumor activity of new mitomycin A analogues. J. Med. Chem. 30: 168 173; 1987

9) Imal, R. \& M. Morimoto: Comparative antitumor activities of $7-N$-( $p$-hydroxyphenyl)mitomycin $\mathrm{C}(\mathrm{M}-83)$ and mitomycin C. J. Antibiotics 36: 559 565, 1983

10) Sasaki, H.; M. Fukumoto, M. Hashida, T. Kimura \& H. Sezaki: Development of lipophilic prodrugs of mitomycin C. 3. Physicochemical and biological properties of newly synthesized alkoxycarbonyl derivatives. Chem. Pharm. Bull. 31: 4083 4090, 1983

11) Kasai, M.; K., Shirahata \& M. Morimoto: New mitomycin derivatives, $7-N$-(omega-acylthioalkyl)mitomycins. Abstracts of the 3rd Chemical Congress of North America: MEDI, 55, Toronto, June 5 10, 1988

12) Kono, M.; Y. Saitoh, M. Kasai, A. Sato, K. Shirahata, M. Morimoto \& T. Ashizawa: Synthesis and antitumor activity of a novel water soluble mitomycin analog; 7-N-[2-[[2-( $\gamma$-L-glutamylamino)ethyl]dithio]ethyl]mitomycin C. Chem. Pharm. Bull. 37: 1128 1130, 1989

13) Shirahata, K.; M. Morimoto, T. Ashizawa, K. Mineura, M. Kono, Y. Saito \& M. Kasai: The structures and biological activities of mitomycin minor components and their related compounds. Program and Abstracts of the 21 st Intersci. Conf. on Antimicrob. Agents Chemother., No. 421, Chicago, Nov. 4 6, 1981

14) Urakawa, C.; H. Tsuchiya \& K. Nakano: New mitomycin, 10-decarbamoyloxy-9-dehydromitomycin B from Streptomyces caespitosus. J. Antibiotics 34: 243 244, 1981

15) Kono, M.; Y. Saitoh, K. Shirahata, Y. Arai \& S. Ishil: Albomitomycin A and isomitomycin A: Products of novel intramolecular rearrangement of mitomycin A. J. Am. Chem. Soc. 109: 7224 7225, 1987

16) Urakawa, C; H. TsuchiYa, K. Nakano \& N. Nakamura: Preparation and biological activities of 10-decarbamoyloxy-9-dehydromitomycin B and its analogs. J. Antibiotics 34: 1152 1156, 1981

17) Kono, M.; M. Kasai, M. \& K. ShIRahata: Improved synthesis of mitomycin G. Synth. Commun. 19: 2041 2047, 1989

18) Arai, T. \& S. Tomohiro (Kyowa Hakko Kogyo): Manufacture of mitomycin B with Streptomyces caespitosus. Jpn. Pat. 207394 ('88) Aug. 26, 1988

19) Matsui, M.; Y. Yamada, K. UzU \& T. Hirata: Studies on mitomycins. III. The synthesis and properties of mitomycin derivatives. J. Antibiotics 21: $189 \sim 198,1968$

20) Kinoshita, S.; K. Uzu, K. Nakano \& T. Takahashi: Mitomycin derivatives. 2. Derivatives of decarbamoylmitosane and decarbamoylmitosene. J. Med. Chem. 14: 109 112, 1971

21) Kinoshita, S.; K. Uzu, K. Nakano, M. Shimizu, T. Takahashi, S. Wakaki \& M. Matsui: The chemical transformation of mitomycins: The structure-activity relationship of mitomycin derivatives. In Progress in Antimicrobial and Anticancer Chemotherapy. Volume II. pp. 1058 1068, Univ. of Tokyo Press, 1970

22) Fukuyama, T.; F. Nakatsubo, A. J. Cocuzza \& Y. Kishi: Synthetic studies toward mitomycins. III. Total syntheses of mitomycins A and C. Tetrahedron Lett. 1977: 4295 4298, 1977

23) Krshi, Y.: The total synthesis of mitomycins. J. Nat. Prod. 42: 549 568, 1979

24) UzU, K.; K. Nakano \& T. TAKahashi (Kyowa Hakko Kogyo): Manufacture of $O$-acyldecarbamoylmitomycins. Jpn. Pat. 25079 ('72), July 8, 1972 
25) Garrett, E. R.: The physical chemical characterization of the products, equilibria, and kinetics of the complex transformations of the antibiotic porfiromycin. J. Med. Chem. 6: 488 501, 1963

26) UzU, K.; Y. Harada, S. WakaKI \& Y. Yamada: Studies on mitomycins, carcinostatic antibiotics. Part II. Mitomycinone. Agric. Biol. Chem. 28: 394 402, 1964

27) Funmoto, K.; T. OKa \& M. MоRiмото: Antitumor activity of a novel antitumor antibiotic, quinocarmycin citrate (KW2152). Cancer Res. 47: 1516 1522, 1987 